\title{
ENZYMES IMPROVE ECF BLEACHING OF PULP
}

\author{
Pratima Bajpai, ${ }^{a^{*}}$ Aradhna Anand ${ }^{\mathrm{a}}$, Nirmal Sharma ${ }^{\mathrm{a}}$, Shree P. Mishra ${ }^{\mathrm{b}}$, Pramod K. Bajpai ${ }^{\mathrm{a}}$ \\ and Dominique Lachenal ${ }^{\mathrm{b}}$
}

\begin{abstract}
The delignification efficiency of different laccase enzymes was examined on the eucalyptus Kraft pulp. The laccase enzyme from Trametes versicolor showing the highest delignification efficiency was selected and used in the elemental chlorine-free bleaching sequence for improving the pulp bleachability. An appreciable reduction in chlorine dioxide consumption was also obtained. Further reduction in chlorine dioxide consumption was obtained when the same laccase treated pulp was subjected to an acid treatment after the extraction stage followed by the $\mathrm{DE}_{\mathrm{P}} \mathrm{D}$ sequence. Elemental-chlorine free bleaching was also performed using the xylanase-laccase treated pulp. Xylanase treatment was incorporated to the laccase mediator system in the elemental-chlorine free bleaching both sequentially and simultaneously. The bleaching sequence $D E_{P} D$ followed and in both the cases, the reduction in chlorine dioxide consumption was greater in comparison to the control. The chlorine dioxide consumption was reduced further when xylanaselaccase treated pulp was given an additional acid treatment. The final pulp properties of the treated pulps were comparable to the control pulp.
\end{abstract}

Keywords: Laccase, Mediator, Delignification, ECF bleaching, Xylanase, Chlorine dioxide

Contact information: a: Thapar Centre for Industrial Research \& Development, Patiala, 147004, India; b: École Française de Papeterie et des Industries Graphiques, BP 65, 38402, Saint Martin D’heres,

France; *Corresponding author: pratima@thaparresearch.org

\section{INTRODUCTION}

Increasing awareness about environmental concerns has led the paper industry to look for cleaner production options aimed at the reduced consumption of chlorine and its compounds in the bleaching sequences which thereby minimizes the discharge of chlorinated organics in the effluent, i.e., AOX. (Mishra et al. 2001). These organochlorine compounds are produced mainly by the reactions between residual lignin present in wood fibers and the chlorine used for bleaching. Some of these compounds are found to be toxic, mutagenic, persistent, bioaccumulating, and harmful to biological systems (Bajpai and Bajpai 1996).

Elemental chlorine-free (ECF) bleaching for the pulp and paper industry, based on chlorine dioxide, offers a number of fundamental benefits over the traditional methods. The U.S. EPA's Cluster Rule for the pulp and paper industry has ECF as one of its core Best Available Technology (BAT) elements (Pryke 1997). In addition to producing the highest pulp quality, ECF bleaching has proven itself to be a pollution prevention process for the pulp and paper industry. Perhaps most important is the fact that the use of chlorine dioxide in the first stage of chemical pulp bleaching virtually eliminates dioxins and 12 
priority chlorophenols proposed by the U.S. Environmental Protection Agency (EPA) for regulation to non-detect levels. The other benefits of ECF bleaching are that it decreases chloroform formation and total chlorinated organic compound (AOX) formation by $90 \%$; efficiently utilizes forest resources; contributes to eco-system recovery; and is compatible with emerging minimum-impact mill technologies (Pryke 1997).

The use of biotechnology in pulp bleaching has attracted considerable attention and achieved interesting results in recent years (Bajpai and Bajpai 1996; Bajpai et al. 2005; Call 1999; Sariaslani 1989 and Paice et al. 1995a). The incorporation of enzymes into the ECF technology can be of further benefit in terms of consumption of bleach chemicals followed by the amount of pollution generation. Enzyme prebleaching using xylanase enzymes offers a solution by improving the effectiveness of bleaching chemicals in removing lignin (Bajpai and Bajpai 1996; Viikari 1994; Roncero 2005; Kansoh 2004; Sudha 2003). Xylanase enzymes are reported to partially hydrolyze the hemicelluloses portion of pulp. It is presumed that the enzyme hydrolyzes xylan into smaller fragments allowing lignin associated with these short hemicelluloses chains to be more easily removed during subsequent extraction stages in bleaching. Xylanase-aided bleaching is an indirect method which does not directly degrade lignin and thus, has a limited effect (Bajpai and Bajpai 1996; Kansoh 2004; Sudha 2003).

Another potential candidate is a laccase enzyme, which selectively decomposes the lignin in the fiber (Paice et al. 1995a; Call and Muck 1994; Call and Muck 1995a; Call and Muck 1995b; Paice et al. 1995b; Reid and Paice 1994; Kondo 1994; Kondo et al 1995; Bourbonnais and Paice 1996; Camarero et al. 2004; Fu et al. 2000; Kandioller and Christov 2001; Crestini et al. 2003; Nelson et al. 1998). Laccases belong to the multicopper oxidases, which can reduce elemental oxygen to water in a four-electron step and simultaneously perform a one-electron oxidation of many aromatic substrates (Paice et al. 1995a; Reinhammer 1984). However, this enzyme alone is not able to delignify the pulp; it requires a mediator to become effective (Bourbonnais and Paice 1990). The mediator is a small redox molecule that acts as a "diffusible electron carrier" or "electron shuttle" between lignin and laccase. It is assumed that the mediator is needed because the large laccase molecule cannot enter the secondary cell wall and oxidize lignin directly. In the laccase mediator concept, the oxidized mediator acts directly on lignin and results in efficient delignification. The use of this enzyme is expected to have a lower impact on the environment by eliminating the use of chlorine and formation of organochlorine compounds (Call 2001). Its other expected benefits are a lower capital investment, a safe system for selectively removing lignin, and improved pulp yields (Reid and Paice 1994).

The successive combination of the two enzymatic methods, the hydrolytic xylanase and the oxidative laccase-mediator treatment, has previously been shown to increase the delignification efficiency (Herpoel et al 2002; Viikari et al. 1999). In light of the background cited here, attempts have been made to use xylanase and laccase enzymes in ECF bleaching for selective delignification of pulp for environment friendly bleaching. 


\section{EXPERIMENTAL}

Wood samples, infected with fungi, were collected from wood yards of pulp mills and other places. The sample pieces were inoculated in sterilized potato dextrose medium containing bacterial inhibitors in $250 \mathrm{ml}$ Erlenmeyer flasks. The flasks were kept under agitation in a shaking incubator at $150 \mathrm{rpm}$ and $30^{\circ} \mathrm{C}$ for $3-4$ days. The fungus mycelium was then streaked on PDA plates. Fungal patches were further streaked on PDA plates many times to get the pure fungal colonies. The pure colonies were inoculated on slants for screening of laccase producing strains. The PDA slants were stored at $4^{\circ} \mathrm{C}$ until used.

Fungal cultures were inoculated in $50 \mathrm{ml}$ sterilized potato dextrose medium in 500 $\mathrm{ml}$ Erlenmeyer flasks, incubated at $27-30^{\circ} \mathrm{C}$ and $60-70 \%$ relative humidity in an incubator. The laccase activity in culture broth of each culture was determined by monitoring the oxidation of 2,2'-azino-bis(3-ethylbenzthiazoline-6-sulfonic acid) (ABTS) as increased absorbance at $420 \mathrm{~nm}$. The reaction mixture contained $2.5 \mathrm{ml}$ of $0.1 \mathrm{M}$ sodium acetate buffer $\mathrm{pH} 5.0,0.17 \mathrm{ml}$ of the enzyme sample and $0.33 \mathrm{ml} 5 \mathrm{mM}$ ABTS, in a final volume of $3.0 \mathrm{ml} .1 \mathrm{U}$ is the amount of enzyme that converts $1 \mu \mathrm{mol}$ substrate in one minute under the described conditions at $25^{\circ} \mathrm{C}$.

Eucalyptus wood chips were procured from a pulp and paper mill in North India. Pulping was done in a rotary autoclave digester by Kraft process. Numerous experiments were performed at different temperatures, time, and active alkali doses to optimize the pulping conditions to obtain a pulp of kappa number 18-19.

The efficacy of laccase enzymes for delignification of eucalyptus pulp was studied at a pulp consistency of $15 \%$, temperature $45^{\circ} \mathrm{C}, \mathrm{pH} 4.0$ for 5.5 hours at different dose levels using HBT as mediator. The enzyme showing maximum delignification was selected and used for further studies. The xylanase treatments were carried out at a pulp consistency of $10 \%$, temperature $50^{\circ} \mathrm{C}, \mathrm{pH} 8$, time 2 hours and enzyme dose $0.075 \%$ (Pulpzyme HC from Novozymes).

ECF bleaching of laccase and xylanase-laccase treated pulps was conducted using a $\mathrm{DE}_{\mathrm{P}} \mathrm{D}$ sequence. The bleaching sequence followed for the reference sample was $\mathrm{DE}_{\mathrm{P}} \mathrm{DD}$. Acid treatment was conducted at $\mathrm{pH} 2,90^{\circ} \mathrm{C}$, for 2 hours at $10 \%$ consistency. Xylanase treatment was incorporated both sequentially and simultaneously. The effect of acid treatment in both the cases was also studied. The final pulps were characterized for optical properties.

Kappa number, a measure of residual lignin in the pulp, was determined as per Tappi test method T 236 om-99. The solution viscosity of a pulp gives an indication of the average degree of polymerization of the cellulose. The viscosity of pulp was determined by capillary viscometer method using Tappi test method T 230 om-99. Such a test gives a relative indication of the degradation (decrease in cellulose molecular weight) resulting from the pulping and/or bleaching process. The brightness and CIE whiteness of the pulp were measured using Technibrite TB 1c instrument as per Tappi test method T525 om-02 and T 560 pm-96, respectively. The brightness reversion of the pulp was estimated in terms of post colour (PC) number according to Tappi test method T 260 om85 . 


\section{RESULTS AND DISCUSSION}

Eucalyptus pulp of kappa number 18.2 was prepared in the laboratory. The unbleached pulp yield was $42 \%$ with a pulp viscosity of $10 \mathrm{cp}$. Where the pulp yield is defined as the mass of pulp (oven dry basis) divided by mass of wood chips (oven dry basis) and expressed as percentage.

Four enzymes, two of Trametes species (Laccase-1 \& Laccase-2) and other two of Aspergillus species (Laccase-3 \& Laccase-4) were selected. To determine the delignification efficiency of laccase enzymes, the treatment of eucalyptus pulp was done in a rotary autoclave digester with different laccase enzymes and mediator (HBT). Laccase-1 and Laccase-2 showed maximum delignification with $60 \mathrm{U}$ enzyme/g of pulp whereas Laccase-3 and Laccase-4 showed maximum delignification with $120 \mathrm{U}$ and 400 $\mathrm{U}$ enzyme/g pulp, respectively. Delignification efficiency was $48 \%, 50 \%, 15 \%$ and $27 \%$ in case of Laccase-1, Laccase-2, Laccase-3 and Laccase-4, respectively (Table 1). Laccase-1 was selected for the bleaching studies, as it showed the highest delignification rate. With Laccase-1 enzyme, maximum delignification occurred at $45^{\circ} \mathrm{C}, \mathrm{pH} 4.0-5.5$ (adjusted with sodium acetate buffer), retention time 3.0-5.0 hours, pulp consistency $15.0 \%$, oxygen pressure $10 \mathrm{~kg} / \mathrm{cm}^{2}$, enzyme dose $60 \mathrm{U} / \mathrm{g}$ and mediator dose $3 \%$ (Table 2 ). Laccase-mediator treated pulps were then alkali extracted using hydrogen peroxide. The brightness and kappa number of the pulp were 48\% ISO and 6.3, respectively. To know the effect of $E_{P}$ alone and $E_{P}$ followed by acid treatment, experiments were conducted without any enzyme. The kappa number of pulp dropped to 12.0 on extraction alone $\left(\mathrm{E}_{\mathrm{P}}\right)$, in the beginning, which reduced further to 10.8 (results not shown in the Table) on acid treatment (after EPA).

Table 1. Delignification of Eucalyptus Kraft Pulp* with Different Laccase Enzymes

\begin{tabular}{|c|c|c|c|c|c|}
\hline Parameter & Laccase- $1^{a}$ & ${\text { Laccase }-2^{b}}^{b}$ & 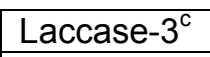 & 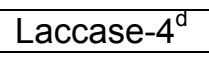 & Control \\
\hline LE $_{p}$ stage Kappa no. & 6.3 & 6.1 & 10.3 & 9.0 & 12.1 \\
\hline $\begin{array}{l}\text { Reduction in kappa no. } \\
\text { (\%) by laccase treatment }\end{array}$ & 48.0 & 50.0 & 14.9 & 27 & - \\
\hline $\begin{array}{l}\text { LE }_{\mathrm{p}} \text { stage brightness (\% } \\
\text { ISO) }\end{array}$ & 48.0 & 48.9 & 35.2 & 34.5 & 31.5 \\
\hline $\begin{array}{l}\text { *Kappa number 18.2; Kap } \\
\text { Conditions: } \\
\text { Laccase-1 \& Laccase-2: } \\
\text { residence time } 5.5 \text { h; cons } \\
\text { Laccase-3: Enzyme dose } \\
\text { consistency } 15 \% \text {; } \mathrm{O}_{2} \text { pres } \\
\text { Laccase-4: Enzyme dose } \\
\text { consistency } 15 \% ; \mathrm{O}_{2} \text { pres } \\
\text { E }_{\mathrm{p}} \text { stage: } \mathrm{NaOH} 1.5 \% \text {; } \mathrm{H}_{2} \\
\text { aLaccase-1: from Tramete } \\
\text { 'Laccase-3: from Aspergill }\end{array}$ & $\begin{array}{l}120 \mathrm{U} / \mathrm{g} ; \mathrm{HB} \\
\text { istency } 15 \% \text { kg/cm } \\
400 \mathrm{U} / \mathrm{g} ; \mathrm{HB} \\
\text { ure } 10 \mathrm{~kg} / \mathrm{cm} \\
\mathrm{O}_{2} 0.5 \% \text {; tem }\end{array}$ & $\begin{array}{l}\text { ose } 3 \% ; \mathrm{pH} \\
\text { ose } 3 \% ; \mathrm{pH} \\
0{ }^{\circ} \mathrm{C} \text {; reside } \\
\mathrm{D}-2{ }^{\mathrm{b}} \text { Lacca }\end{array}$ & 5; temp. 45 & ${ }^{\circ} \mathrm{C}$; residen & $\begin{array}{l}\text { mp. } 45^{\circ} \mathrm{C} \\
\text { time } 5.5 \mathrm{~h} \\
\text { time } 5.5 \mathrm{~h} \\
\text { TCIRD-6, }\end{array}$ \\
\hline
\end{tabular}


The results of ECF bleaching of laccase treated pulps are shown in Table 3. An appreciable reduction in chlorine dioxide consumption was observed. Chlorine dioxide demand reduced to $45.6 \%$ in comparison to the reference sample (Tables 3 and 4 ). When the same laccase treated pulp was subjected to an acid treatment $(\mathrm{pH} 2$, temperature $90^{\circ} \mathrm{C}$, time $2 \mathrm{~h}$, consistency $10 \%$ ) after the extraction stage followed by $\mathrm{DE} \mathrm{P}_{\mathrm{P}} \mathrm{D}$ sequence, there was a remarkable effect of the acid treatment on the same pulp in the same conditions. The reduction in the chlorine dioxide dose increased to $58.1 \%$ in comparison to the control (Tables 3 and 4). This reflected the encouraging role of acid treatment on the laccase-mediator bleaching system.

Table 2. Optimum Conditions of Delignification by Laccase-1

\begin{tabular}{|l|c|}
\hline Parameter & Value \\
\hline Enzyme dose $(\mathrm{U} / \mathrm{g})$ & 60 \\
\hline Mediator $(\mathrm{HBT})$ dose $(\%)$ & 3 \\
\hline Consistency $(\%)$ & 15 \\
\hline $\mathrm{pH}$ & 4.0 \\
\hline Temperature $\left({ }^{\circ} \mathrm{C}\right)$ & 45 \\
\hline Time $(\mathrm{h})$ & 5 \\
\hline $\mathrm{O}_{2}$ pressure $\left(\mathrm{kg} / \mathrm{cm}^{2}\right)$ & 10 \\
\hline
\end{tabular}

Table 3. Effect of Laccase-Mediator System on ECF Bleaching

\begin{tabular}{|c|c|c|c|}
\hline Parameter & $D_{O} E_{P}^{*} D_{1} D_{2}$ & LEp ${ }^{\star \star} D O E p^{* \star *} D_{1}$ & $\mathrm{LE}_{\mathrm{P}}{ }^{* \star} \mathrm{A} \mathrm{D}_{\mathrm{O}} \mathrm{Ep}^{* * *} \mathrm{D}_{1}$ \\
\hline Kappa factor & 0.28 & 0.15 & 0.12 \\
\hline Reduction in $\mathrm{ClO}_{2}$ Dose (\%) & - & 45.6 & 58.1 \\
\hline LEp ${ }^{\star \star}$ Brightness (\%ISO) & - & 46.4 & - \\
\hline LEp**A Brightness (\%ISO) & - & - & 47.0 \\
\hline $\mathrm{D}_{\mathrm{O}}$ Brightness (\%ISO) & 42.0 & 66.8 & 63.5 \\
\hline$E_{P}^{*}$ Brightness (\%ISO) & 65.2 & & - \\
\hline Ep ${ }^{\star * *}$ Brightness (\%ISO) & - & 79.4 & 78.9 \\
\hline $\mathrm{D}_{1}$ Brightness (\%ISO) & 84.5 & 88.0 & 88.2 \\
\hline $\mathrm{D}_{2}$ Brightness (\%ISO) & 87.8 & - & - \\
\hline Viscosity $(\mathrm{cp})$ & 7.2 & 7.1 & 6.9 \\
\hline \multicolumn{4}{|c|}{$\begin{array}{l}\text { Treatment conditions: } \\
\mathrm{L} \text { stage conditions: Laccase dose } 60 \mathrm{U} / \mathrm{g} \text { pulp, } \mathrm{HBT} \text { dose } 3 \% \text {, pH } 4.0 \text {, temp. } 45{ }^{\circ} \mathrm{C} \text {, consistency } \\
15 \% \text { and retention time } 5 \mathrm{~h} \\
\text { A stage conditions: } \mathrm{pH} 2 \text {, temp. } 90{ }^{\circ} \mathrm{C} \text {, retention time } 2 \mathrm{~h} \text {, consistency } 10 \% \\
\text { Ep stage conditions: } \mathrm{NaOH} \text { dose } 0.85 \%, \mathrm{H} 2 \mathrm{O} 2 \text { dose } 0.5 \% \text {, temp. } 70{ }^{\circ} \mathrm{C} \text {, consistency } 10 \% \text { and } \\
\text { retention time } 2 \mathrm{~h} \\
\text { Ep } \\
\text { retention time } 2 \mathrm{~h} \\
\text { Ep } \\
\text { retention time } 2 \mathrm{~h} \\
\mathrm{D}_{\mathrm{O}}^{* * *} \text { stage conditions: } \mathrm{pH} 3.5 \text {, temp. } 55{ }^{\circ} \mathrm{C} \text {, retention time } 30 \text { min, consistency } 10 \% \\
\mathrm{D}_{1} \text { stage conditions: } \mathrm{ClO}_{2} \text { dose } 0.8 \%, \mathrm{pH} 3.5 \text {, temp. } 75^{\circ} \mathrm{C} \text {, retention time } 3 \mathrm{~h} \text {, consistency } 10 \% \\
\mathrm{D}_{2} \text { stage conditions: } \mathrm{ClO}_{2} \text { dose } 0.4 \%, \mathrm{pH} 3.5 \text {, temp. } 75^{\circ} \mathrm{C} \text {, retention time } 3 \mathrm{~h} \text {, consistency } 10 \%\end{array}$} \\
\hline
\end{tabular}

The results of ECF bleaching of xylanase-laccase treated pulp are shown in Tables 4 and 5. The bleaching sequence followed for the reference sample and the xylanase-laccase treated sample was the same as followed for the laccase mediator 
bleaching system. It was observed that laccase treated pulp shows a cumulative effect along with xylanase treatment.

When only laccase treated pulp was used, the chlorine dioxide demand was reduced to $45.6 \%$ in comparison to the control sample, which increased to $55 \%$ when xylanase treatment was also included to the same laccase mediator bleaching system (Tables 4 and 5). Both the simultaneous and sequential combination of xylanases with laccase-mediator bleaching systems showed the same reduction in the bleach chemical consumption. Similar results were reported by Herpoel et al. (2002) with wheat straw pulp where up to $60 \%$ reduction in kappa number was obtained after xylanase and laccase sequential treatments, followed by alkaline extraction.

The addition of the acid treatment stage to the xylanase-laccase treated pulp led to further reduction in the chemical consumption to $67.4 \%$ rather than $55 \%$ when no acid treatment was involved. There was no difference in the results of sequential and simultaneous treatments of xylanase application (Tables 4 and 5). As a parallel experiment for the sake of comparison, the pulp was acid treated without any laccase treatment. There was a decrease in kappa number by 1.5 points (about $8.2 \%$ ) only but the reduction in chlorine dioxide consumption in $\mathrm{AD}_{0} \mathrm{E}_{\mathrm{P}} \mathrm{D}_{1} \mathrm{D}_{2}$ bleaching sequence was about $15 \%$ (results not shown in Tables), which indicated the potential of acid treatment.

Table 4. Bleach Chemical Requirements

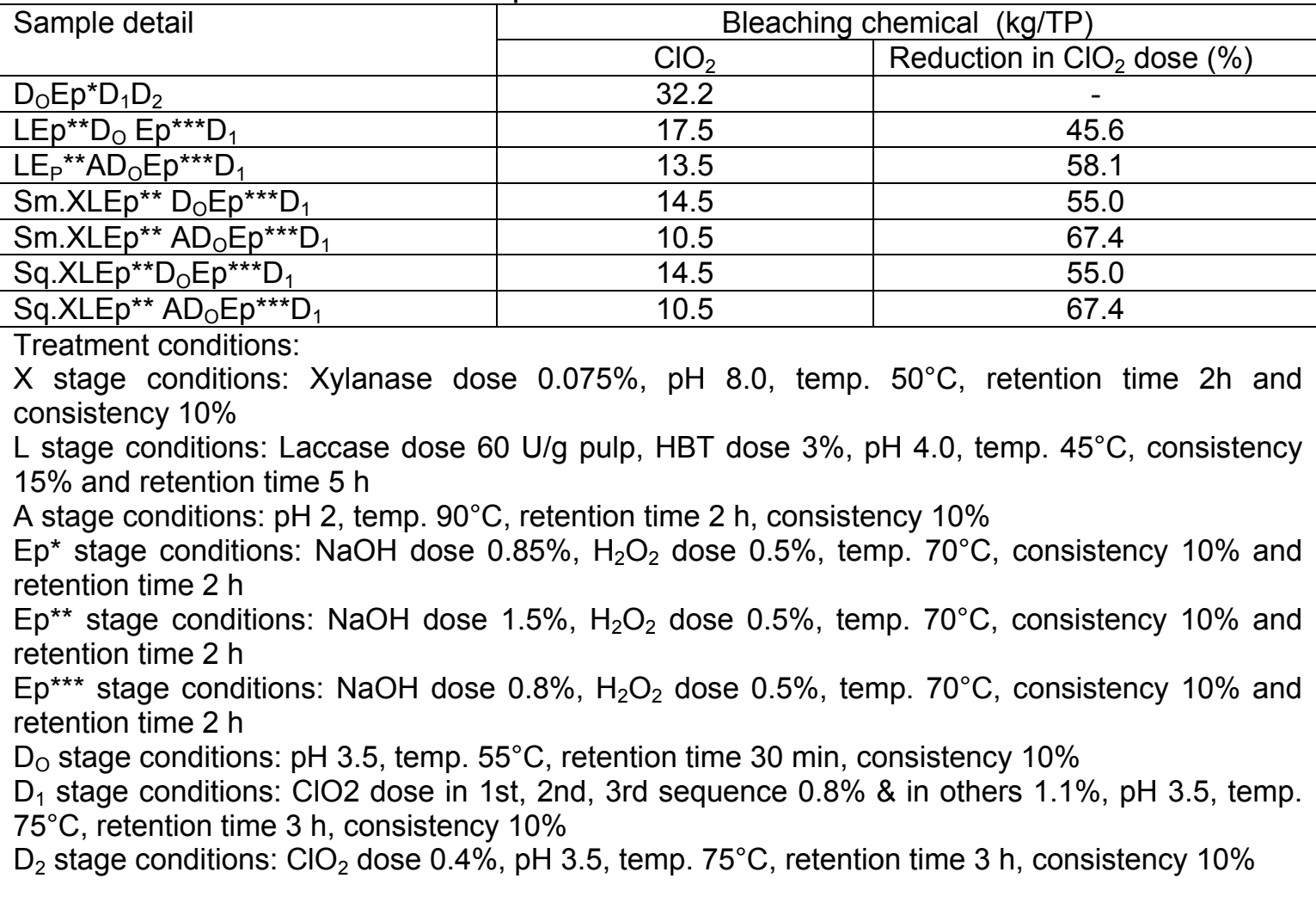


Table 5. Effect of Xylanase Treatment on the Laccase-Mediator Bleaching System

\begin{tabular}{|c|c|c|c|c|c|}
\hline Parameter & $D_{O} E p^{*} D_{1} D_{2}$ & $\begin{array}{l}\text { Sm.XLEp } p^{* *} \\
D_{0} E p^{* * *} D_{1}\end{array}$ & $\begin{array}{l}\text { Sm.XLEp } p^{* *} A \\
D_{0} E p^{* * *} D_{1}\end{array}$ & $\begin{array}{l}\text { Sq.XLEp } p^{* *} \\
D_{0} E p^{* * *} D_{1}\end{array}$ & $\begin{array}{l}\text { Sq.XLEp }{ }^{* *} A \\
D_{0} E p^{* * *} D_{1}\end{array}$ \\
\hline Kappa factor & 0.28 & 0.12 & 0.09 & 0.12 & 0.09 \\
\hline Reduction in $\mathrm{ClO}_{2}$ dose & - & 55.0 & 67.4 & 55.0 & 67.4 \\
\hline Ep* Brightness (\%ISO) & 65.2 & - & - & - & - \\
\hline $\begin{array}{l}\text { XLEp }{ }^{* \star} \text { Brightness } \\
(\% \text { ISO) }\end{array}$ & - & 49.5 & - & 49.2 & - \\
\hline $\begin{array}{l}\text { XLEp }{ }^{* *} \text { A Brightness } \\
(\% \text { ISO) }\end{array}$ & - & - & 50.3 & - & 50.0 \\
\hline $\mathrm{D}_{\mathrm{O}}$ Brightness (\%ISO) & 42.0 & 67.8 & 62.9 & 68.1 & 62.7 \\
\hline Ep ${ }^{* * *}$ Brightness (\% & & 79.7 & 77.5 & 77.0 & 77.3 \\
\hline $\mathrm{D}_{1}$ Brightness (\%l & 84.5 & 88.3 & 88.0 & 88.0 & 87.9 \\
\hline $\mathrm{D}_{2}$ Brightness (\%l & 87.8 & - & - & - & - \\
\hline Viscosity (cP) & 7.2 & 7.0 & 6.8 & 7.0 & 6.8 \\
\hline \multicolumn{6}{|c|}{$\begin{array}{l}\text { Treatment conditions: } \\
\text { X stage conditions: Xylanase dose } 0.075 \% \text {, pH } 8.0 \text {, temp. } 50{ }^{\circ} \mathrm{C} \text {, retention time } 2 \mathrm{~h} \text { and } \\
\text { consistency } 10 \% \\
\text { L stage conditions: Laccase dose } 60 \mathrm{U} / \mathrm{g} \text { pulp, } \mathrm{HBT} \text { dose } 3 \% \text {, pH } 4.0 \text {, temp. } 45{ }^{\circ} \mathrm{C} \text {, consistency } \\
15 \% \text { and retention time } 5 \mathrm{~h} \\
\text { A stage conditions: } \mathrm{pH} 2 \text {, temp. } 90{ }^{\circ} \mathrm{C} \text {, retention time } 2 \mathrm{~h} \text {, consistency } 10 \% \\
\text { Ep* stage conditions: } \mathrm{NaOH} \text { dose } 0.85 \%, \mathrm{H}_{2} \mathrm{O}_{2} \text { dose } 0.5 \% \text {, temp. } 70{ }^{\circ} \mathrm{C} \text {, consistency } 10 \% \text { and } \\
\text { retention time } 2 \mathrm{~h} \\
\text { Ep } \\
\text { retention time } 2 \mathrm{~h} \\
\text { Ep } \\
\text { retention time } 2 \mathrm{~h} \\
\text { Do stage conditions: } \mathrm{pH} 3.5 \text {, temp. } 55{ }^{\circ} \mathrm{C} \text {, retention time } 30 \text { min, consistency } 10 \% \\
\mathrm{D}_{1} \text { stage conditions: } \mathrm{ClO}_{2} \text { dose in } 1 \mathrm{st} \text { sequence } 0.8 \% \text { and in others } 1.1 \% \text {, pH } 3.5 \text {, temp. } 75{ }^{\circ} \mathrm{C} \text {, } \\
\text { retention time } 3 \mathrm{~h} \text {, consistency } 10 \% \\
\mathrm{D}_{2} \text { stage conditions: } \mathrm{ClO}_{2} \text { dose } 0.4 \%, \mathrm{pH} 3.5 \text {, temp. } 75{ }^{\circ} \mathrm{C} \text {, retention time } 3 \mathrm{~h} \text {, consistency } 10 \% \\
\end{array}$} \\
\hline
\end{tabular}

The final pulps were characterized and it was found that the pulp properties were comparable to the reference sample, which shows that the laccase-mediator system does not affect the properties of the pulp (Table 6). Poppius-Levlin et al. (1999) have also reported that although laccase treatment temperature, laccase charge and mediator charge had pronounced effect on lignin reactions, their effect on pulp properties was insignificant.

About $43 \%$ reduction in kappa number of Eucalyptus kraft pulp after laccase treatment and alkaline extraction has been achieved by $\mathrm{Fu}$ et al. (2000), whereas bleaching of high kappa kraft pulps of different raw materials with a laccase mediator system provided $43-61 \%$ reduction in kappa number after E+P stage, using violuric acid as mediator (Chandra et al. 2001). Kandioller and Christopher (2004) have also reported various degrees of delignification depending on the pulp type, enzyme and mediator charge using laccase mediator treatment followed by alkaline extraction. By repeated laccase treatment and alkaline extraction (reinforced with oxygen and hydrogen peroxide), up to $80 \%$ reduction in kappa number was obtained by Sealey et al (1997). 
This indicates that the laccase mediator treatment is capable of reacting with vestiges of residual lignin, which are typically very unreactive.

Further work on the effects of initial alkali extraction $\left(\mathrm{E} / \mathrm{E}_{\mathrm{P}} / \mathrm{E}_{\mathrm{OP}}\right.$ stage) and /or acid treatment (A stage) followed by conventional ECF, with and without the laccase mediator system under different conditions, is in progress.

Table 6. Bleached Pulp Properties

\begin{tabular}{|c|c|c|c|c|}
\hline Bleaching sequence & $\begin{array}{c}\text { Final } \\
\text { brightness } \\
(\% \text { ISO) }\end{array}$ & $\begin{array}{l}\text { Final viscosity } \\
\text { (cP) }\end{array}$ & $\begin{array}{l}\text { CIE whiteness } \\
(\% \text { ISO })\end{array}$ & P.C. number \\
\hline$D_{0} E p^{*} D_{1} D_{2}$ & 87.9 & 7.2 & 80.0 & 0.28 \\
\hline LEp $^{\star *} \mathrm{D}_{\mathrm{O}} E \mathrm{Ep}^{\star * *} \mathrm{D}_{1}$ & 88.0 & 7.1 & 81.1 & .27 \\
\hline LE $_{\mathrm{P}}{ }^{* *} \mathrm{~A} \mathrm{D}_{\mathrm{O}} E \mathrm{E}^{* * *} \mathrm{D}_{1}$ & 88.2 & 6.9 & 81.2 & .26 \\
\hline Sm.XLEp $p^{* *} D_{0} E p^{* * *} D_{1}$ & 88.3 & 7.0 & 82.0 & .25 \\
\hline Sm.XLEp ${ }^{\star *} A D_{0} E p^{* * *} D_{1}$ & 88.0 & 6.8 & 82.0 & 26 \\
\hline Sq.XLEp $p^{* \star} D_{o} E p^{* * *} D_{1}$ & 88.0 & 7.0 & 82.2 & .25 \\
\hline Sq.XLEp** $A D_{0} E p^{* * *} D_{1}$ & 88.0 & 6.8 & 82.3 & 0.25 \\
\hline \multicolumn{5}{|c|}{ 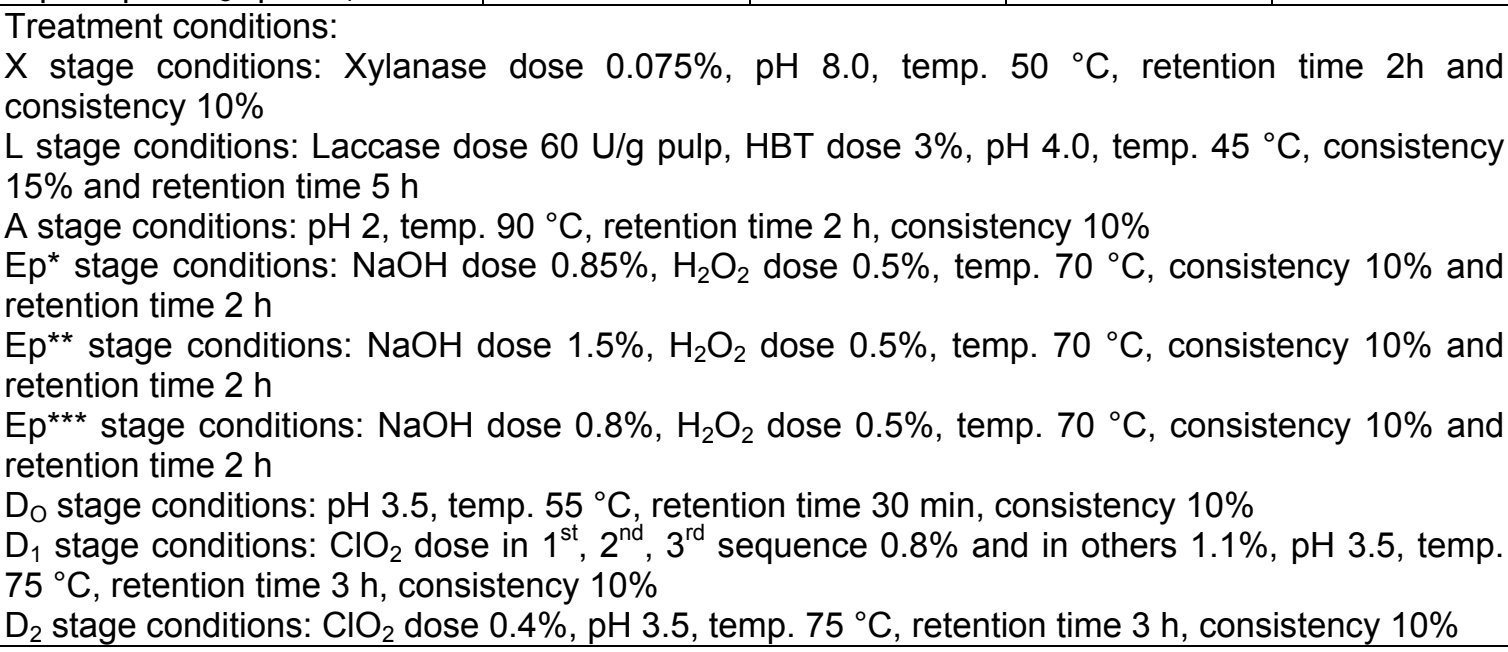 } \\
\hline
\end{tabular}

\section{CONCLUSIONS}

Based on the bleaching experiments performed in this study, it is concluded that the enzymes have an encouraging role in reducing the chemical consumption during elemental-chlorine-free bleaching. Upon implementation, the applications from the present findings can be expected to help reduce the amount of pollutants that are produced during future manufacture of bleached kraft pulp.

\section{ACKNOWLEDGMENTS}

The authors thank Indo-French Centre for the Promotion of Advanced Research (IFCPAR) for providing financial support. 


\section{REFERENCES CITED}

Bajpai, P., and Bajpai, P. K. (1996). "Realities and trends in enzymatic prebleaching of Kraft pulp," Adv. Biochem. Eng. Biotechnol., T. Schepper, ed., Springer-Verlag, Berlin, 56, pp. 1-31.

Bajpai, P., Anand, A., Sharma, N., Bajpai, P. K., Mishra, S. P., and Lachenal, D. (2005). "Bleaching of eucalyptus Kraft pulp with laccase-mediator system," In: Proc. 2005 International Pulp Bleaching Conference, June 14-16, Stockholm, Sweden, pp 306308.

Bourbonnais, R., and Paice, M. G. (1990). "Oxidation of non-phenolic substrates. An expanded role for laccase in lignin degradation," FEBS Lett. 267, 99.

Bourbonnais, R., and Paice, M. G. (1996). "Enzymatic delignification of Kraft pulp using laccase and a mediator," Tappi. J. 76(6), 199-204.

Call, H. P. (1999). "New enzymatically mediated delignification and bleaching systems," In: $10^{\text {th }}$ International Symposium on Wood and Pulping Chemistry - 10th Biennial ISWPC-Main Symposium, Yokohama, Japan, (1), 540-545.

Call, H. P. (2001). "New developments in enzyme assisted delignification and bleaching," In: Proc. 8th Int. Conf. Biotech. in Pulp and Paper Industry, Helsinki, Finland, 60.

Call, H. P., and Mucke, I. (1994). "Enzymatic bleaching of pulps with the laccasemediator system," In: Pulping Conference AIChE session, San Diego, CA, USA, 3852.

Call, H. P., and Mucke, I. (1995a). "Further improvements of the Laccase-Mediatorsystem (LMS) for enzymatic delignification and results from large scale trials," In: Int. Non-Chlorine Bleaching Conf., Amelia Island, Florida, USA, 16pp.

Call, H. P., and Mucke, I. (1995b). "The laccase-mediator-system (LMS)," Biotechnology in the Pulp and Paper Industry: Recent Advances in Applied and Fundamental Research (Proc. $6^{\text {th }}$ Int. Conf. Biotech. Pulp and Paper Industry), E. Srebotnik and K. Messner, eds., Vienna, Austria, 27-32.

Camarero, S., Garcia, O., Vidal, T., Colom, J., Delrio, J. C., Gutierrez, A., Gras, J. M., Monje, R., Martinez, M. J., and Martinez, A. T. (2004). "Efficient bleaching of nonwood high-quality paper pulp using laccase-mediator system," Enzyme and Microbial. Technol. 35(2-3), 113-120.

Chandra, R. P., Chakar, F. S., Allison, L., Kim, D. H., Ragauskas, A. J., and Elder, T. (2001). "Delving into the fundamental LMS delignification of high kappa Kraft pulps," In: Proc. $8^{\text {th }}$ Int. Conf. Biotech. Pulp and Paper Industry, 4-8 June 2001, Helsinki, Finland, 54.

Crestini, C., Jurasek, L., and Argyropoulos, D. S. (2003). "On the mechanism of the laccase-mediator system in the oxidation of lignin," Chemistry 9(21), 5371-5378.

Fu, S., Zhan, H., and Yu, H. (2000). "Preliminary study on biobleaching of Eucalyptus urophylla Kraft pulp with laccase-mediator system," China Pulp Pap. 19(2), 8-15.

Herpoel, I., Jeller, H., Fang, G., Petit-Conil, M., Bourbonnais, R., Robert, J.-L., Ashther, M., and Sigoillot, J.-C. (2002). "Efficient enzymatic delignification of wheat straw pulp by a sequential xylanase-laccase mediator treatment," J. Pulp Pap. Sci. 28(3), $67-71$. 
Kandioller, G., and Christov, L. (2001). "Efficiency of Trametes versicolor laccasemediator systems in pulp delignification and bleaching," In: Proc. $8^{\text {th }}$ Int. Conf. Biotech. In Pulp and Paper Industry, Helsinki, Finland, pp. 223-224.

Kandioller, G., and Christopher, L. (2004). "Delignification efficiency of Trametes Versicolor laccase in combination with various mediators," In: $9^{\text {th }}$ Int. Conf. Biotech. Pulp and Paper Industry. 10-14 Oct 2004, Durban, South Africa, Paper 05.4..

Kanosh, A. L., and Nagieb, Z. A. (2004). "Xylanase and mannanase enzymes from Streptomyces galbus NR and their use in biobleaching of softwood Kraft pulp," Antonie Van Leeuwenhoek 85(2), 103-114.

Kondo, R., Hirai, H., Harazono, K., and Sakai, K. (1995). "Biobleaching of Kraft pulp with lignin-degrading fungi and their enzymes," In: Biotechnology in the Pulp and Paper Industry: Recent Advances in Applied and Fundamental Research (Proc. $6^{\text {th }}$, Int. Conf. Biotech. Pulp and Paper Industry), E. Srebotnik and K. Messner, eds., Vienna, Austria, pp. 33-38.

Kondo, R., Kurashiki, K., and Sakai, K. (1994). "In vitro bleaching of hardwood Kraft pulp by extra cellular enzymes secreted from white-rot fungi in a cultivation system using a membrane filter," Appl. Env. Microbiol. 60, 921-926.

Mishra, D. K., Joshi, H. C., Bhatia, H. S., Chandarana, D. P., and Lakhotia, R. L. (2001). "Enzyme pre-bleaching towards ECF pulp: a successful attempt at Century Pulp and Paper," IPPTA Convention Issue, 5-14.

Nelson, P. J., Chin, C. W. J., Viikari, L., and Tenkanen, M. (1998). "The use of a laccasemediator stage in bleaching of eucalypt Kraft pulps," In: Proc. Int. Pulp Bleaching Conf. Book 2, Helsinki, Finland, pp. 349-354.

Paice, M. G., Bourbonnais, R., Reid, I. D., Archibald, F. S, and Jurasek, L. (1995a). "Oxidative bleaching enzymes," J. Pulp Pap. Sci. 21, J280-J284.

Paice, M. G., Bourbonnias, R., and Reid, I. D. (1995b). "Bleaching Kraft pulps with oxidative enzymes and alkaline hydrogen peroxide," Tappi J. 78(9), 161-170.

Poppius-levlin, K., Tamminen, T., Rajanen, K., Jaaskelainen, A. S., and Viikari, L. (1999). "Suitability of laccase-mediator systems for hardwood Kraft pulp delignification," Proc. Int. Symp. on Wood and Pulping Chemistry - 10th Biennial ISWPC - Main Symposium, Yokohama, Japan, (1), 7-10 June, 1999: Vol. 1, 556.

Pryke, D. C. (1997). "Elemental chlorine-free (ECF): Pollution prevention for the pulp and paper industry," (http://www.ecfpaper.org/science/science.html).

Reid, I. D., and Paice, M. G. (1994). "Biological bleaching of Kraft pulps by white-rot fungi and their enzymes," FEMS Microbiology Reviews, 13, 369-376.

Rein Hammer, B. (1984). "Laccase," In: Copper Proteins and Copper Enzymes., R. Lontie, ed., CRC, Boca Raton, Florida, USA, 1.

Roncero, M. B., Torres, A. L., Colom, J. F., and Vidal, T. (2005). "The effect of xylanase on lignocellulosic components during the bleaching of wood pulps," Bioresource Technol. 96(1), 21-30.

Sariaslani, F. S. (1989). "Microbial enzymes for oxidation of organic molecules," Crit. Rev. Biotechnol. 9, 171-257.

Sealey, J. E., Ragaukas, A. J., and Runge, T. M. (1997). "Biobleaching of Kraft pulps with laccase and hydroxybenzotriazole," Proc. Tappi. Biological Science Symp. 339342. 
Sudha, B., Veermani, H., and Sumathi, S. (2003). "Bleaching of bagasse pulp with enzyme pre-treatment," Water Sci. Technol. 47 (10), 163-168.

Viikari, L., Kantelinen, A., Sundquist, J., and Linko, M. (1994). "Xylanases in bleaching: from an idea to industry," FEMS Microb. Rev. 13, 335-350.

Viikari, L., Oksanen, T., Buchert, J., Amann, M., and Candussio, A. (1999). "Combined action of hemicellulases and oxidases in bleaching," In: $10^{\text {th }}$ International Symposium on wood and pulping chemistry - 10th Biennial ISWPC - Main Symposium, Yokohama, Japan, (1), 504-508.

Article submitted: March 27, 2006; Accepted: May 8, 2006; Published: June 24, 2006 